\title{
The Pattern Language Construction of Landscape Space of Hani Traditional Settlement in Yuanyang, Yunnan Province
}

\author{
Xie Rongxing \\ Southwest Forestry University, Bailong Road 300, Panlong District, Kunming, China \\ Xierongxing2016@gmail.com
}

Keywords: A pattern language, Hani traditional settlement, Landscape spatial composition, Landscape characteristic, Yuanyang

\begin{abstract}
Based on the research method of Christopher Alexander 's "A Pattern Language" theory, the pattern language system of Hani traditional settlement in Yuanyang is constructed. Firstly, macro-level pattern language is settlement is generally located in the concave of hillside. Secondly, meso-level pattern language is the vertical structure landscape elements system of "mountain and forest-building group-terrace-water system" is the most obvious feature. Thirdly, micro-level pattern language is terrace and mushroom house are symbols of landscape in settlement. Mysterious Woods and Swing Square makes the settlement structure and boundary clearly. The water system connects the elements of the harmonious ecological system in series. The construction of pattern language has the immediate significance to promote the protection and development of Hani traditional settlement and other traditional settlements.
\end{abstract}

\section{Introduction}

According to the explanation of a dictionary called "Ci Hai", the meaning of the word "settlement" is villages or tribes inhabited by human. Therefore, the word "settlement" in this article refers to villages. And the traditional settlement refers to the ancient villages formed in the historical period, which still retains obvious historical and cultural characteristics, and the historical features are relatively complete [1,2].

The Hani nationality is mainly distributed between the area of " three rivers and two mountains" in the southern part of Yunnan Province. With the development of a long process, a lot of distinctive, primitive, natural, harmonious and beautiful Hani traditional settlements were formed. Yuanyang County is selected as the research area in this paper. It is located in the south of Yunnan Province, and is one of the counties under the jurisdiction of Honghe Hani and Yi Autonomous Prefecture. Yuanyang County is one of the most important Hani inhabited areas in China, and Hani settlement is characterized by numerous, prominent features, rich ethnic customs and well preserved in this area. Consequently, it is a typical area to study the landscape of Hani traditional settlement. Our research team conducted three field surveys on 18 Hani villages in Yuanyang County from 2014 to 2016, such as Azheke Village, Jingkou Village, Yakou Village and so on. During the investigation, it is found that the landscape characteristics of Hani traditional settlements are facing the risk of disappearing with the climax of the construction of villages and towns in China. The reason is that the operation mode of protection planning on Hani traditional settlement is relatively unitary, and the guidance and planning of it are not considered from the perspective of cultural connotation and national uniqueness. The characteristic landscape of the settlement should be protected and inherited, because it is the concentrated expression of Hani customs, lifestyle, religious belief and so on. It is the gene bank of Hani traditional culture.

This paper used Christopher Alexander's theory of "A Pattern Language" to analyze the landscape characteristics of Hani traditional settlement in Yuanyang, Yunnan Province, extracted the common features and laws about the landscape space of Hani traditional settlement by the method of pattern language, and will provide theoretical basis and practical guidance for theoretical research and practice on the protection and sustainable development of Hani traditional settlement. 


\section{Theoretical basis and research method}

\subsection{Christopher Alexander's theory of "A Pattern Language"}

In 1970s, American architect C•Alexander and his collaborators wrote a series of books, such as The Timeless Way of Building, A Pattern Language, and The Oregon Experiment. Thus it established a theoretical system of pattern language about architecture and planning. C•Alexander's theory about the pattern language takes town, architecture and structure as the basic frame, and from the macro-level to the micro-level, the complex towns and buildings are summed up as 253 simple pattern languages. These pattern languages effect and restrict each other, and they have the order of magnitude and logical relationship. Eventually, they are assembled together to form a complete theoretical system of pattern language.

"The Timeless Way of Building" mentions that every vibrant and integrated society has its own unique and clear pattern language. C.Alexander believes that "pattern" can be understood as a kind of "relationship" or "rule", and they are the units of language, therefore, the pattern languag is a regular system composed of patterns [3]. In addition, C•Alexander's "A Pattern Language" pays attention to describing patterns in language, for the description of language can not only show the external form and characteristics of objects, but also expresses the connotation and meaning to realize the clarity and accuracy of the presentation of pattern.

The theory of $\mathrm{C}$-Alexandria has important reference significance for the study of complex and diverse landscape space about traditional settlement, because the relationship between man and environment is the starting point, and the research method is analyze from the whole to the local, and from the internal links between the various parts to reveal the overall characteristics [4]. Therefore, under the guidance of "A Pattern Language", through observation, analysis and summary, this paper tries to construct the pattern language of Hani traditional settlement.

\subsection{The method and thinking of pattern language extraction about landscape space of Hani traditional settlement}

The main research content of this paper is the elements of landscape space of traditional Hani village in Yuanyang. The research thinking drawing on the overall structure from the macro to the micro of "town $\rightarrow$ architecture $\rightarrow$ architecture" in "A Pattern Language". First of all, Hani traditional settlement in Yuanyang is analyzed from landscape space of overall settlement, spatial structure and layout of settlement, and various elements of settlement. Secondly, the corresponding pattern language is refined. Thirdly, the pattern language with settlement level from the macro to the micro is formed. Finally, the combination of pattern languages in different levels constitutes a complete theory system of pattern language about Hani traditional settlement.

\section{A pattern language of the landscape space of Hani traditional settlement on the macro level}

The overall landscape intention of Hani traditional settlement in Yuanyang is the spectacular terraces wrapping mountains, and they are piled and connected inexhaustibly. Hilltops are covered with mist and dense woods, and in the middle of hills thatched cottages made of mud like clusters of mushrooms are scattered in the mountains and forest terraces.

Hani traditional settlement in Yuan Yang are of all sizes. Each village is separated by terraces. In accordance with the trend mountains of building generally located in the halfway up the mountain according to the relevant description of Hani ancient song in the "ancestral progenitor", the Hani traditional settlements in Yuanyang are mainly located in the semi-mountainous area between 800 and 2000 meters above sea level in Ailao Mountain, Simultaneously, buildings are generally located in the "concave pond" and surrounded by "mountain packages". This area is very suitable for human habitation and is conducive to the production because the valleys in the form of " concave pond " between 800-2000 meters above sea level converge well with abundant rainfall and moderate climate. Here is the wonder land of " wind and air reservoir". 


\section{A pattern language of the landscape space of Hani traditional settlement on the meso level}

\subsection{The landscape space of settlement from plane angle}

Plane morphology is mainly manifested as the characteristics of the circle structure centered on human activities. The center layer of the whole settlement is the building group which are surrounded by a few woods. In addition, the outer circle of settlement is a large area of terraced fields. Therefore, the settlement formed a pattern of planar landscape space that is a circle structure of "building group - woods encirclement - terrace" from inside to outside.

\subsection{The landscape space of settlement from facade angle}

The compositional system of landscape space elements vertically distributed along the altitude is one of the most obvious features of Hani traditional settlement. The upper part of Hani traditional settlement is thick woods, the central part is dense buildings, the lower part is terraced fields that extending to the foot of the river. Consequently, a pattern of vertical landscape space is formed which is "mountain and forest - building group - terrace - water system" from top to bottom. Hani people live in the building group and reclaim terraces below the residential area. The water source in the dense woods above the residential area not only meets the demand of domestic water, but also irrigates the terraces through the scientific water circulation system, at the same time, the rice produced by the terrace feeds industrious and intelligent Hani people [5]. In short, the mountain and forest, building group, terrace, water system and Hani people formed a common whole are interconnected and restrained mutually. In the end, it constitutes a complete and scientific living environment ecosystem of vertical circulation about Hani traditional settlement.

\section{A pattern language of the landscape space of Hani traditional settlement on the micro level}

This section divides the landscape space of settlement into three parts: the interior space of settlement, the boundary space and the exterior space of settlement. The border divides the settlement into interior space and exterior space. On one hand, the exterior space of settlement refers to the environment of site selection, which is composed of terrace, mountain, forest and other natural landscape elements. On the other hand, the interior space of settlement refers to the artificial space, which is composed of building group, road system, water system and landscape nodes.

\subsection{Exterior landscape space of settlement}

\subsubsection{Terrace}

Terrace is the most significant symbol and landscape feature of the Hani Traditional settlement. The artificial terrace is well combined with the natural mountain and forest, and it formed a unique and harmonious natural landscape of Hani traditional settlement.

Hani terrace has more than 1,300 years of history. During the Jiaqing years of Qing Dynasty, " local chronicles of Southern Yunnan " Volume II, " local chronicles of Lin'an Prefecture " records: " The flat foothills were explored into fields, stacked and picturesque. To the extreme mountain, the hierarchy level is terrace according to the natural step up. High water source is connected through the bridge, extending the terraced fields. "At the 37th World Heritage Convention on June 22, 2013, the " Cultural Landscape of Hani Terrace in Honghe Prefecture" was included in the "World Heritage List." Hani terrace is a farming civilization lasting for thousands of years created by Hani's adaptation to nature and the use of nature. It is a model of high harmony between man and nature.

All hillsides allowed by the conditions have been reclaimed into terraces within the Hani settlement in Yuanyang. These terraces are widely distributed, large-scale, strange scenery. Hani terraces built with the mountain topography changes and local conditions, and they stretch endlessly from the foothills to the top of the mountain. A beautiful picture of " mountain gullies as jade, layers of terraces like a ladder which leads to sky" is thus formed.

The landscape of terrace is beautiful and varies with seasons. At the end of winter and early spring every year, Hani terraced fields filled with water are shimmering and changeable under the 
sunshine and against the blue sky. In the end of spring and early summer, layers of terraced fields are green one, and shrouded in clouds looming. When the rice is ripe, the terrace is full of golden hill and valley at the end of summer and early autumn. At the same time, the landscape space of the whole settlement also presents a variety of features with the change of terraced landscape, which makes it more hierarchical and rhythmic.

\subsubsection{Mountain and forest}

The buildings of Hani traditional settlement in Yuanyang built in accordance with the trend of the mountain, and the form, color and texture of the woods constitute the natural background of the settlement landscape. Varied shapes of the settlement are seen in the alternate seasons of the year, elements of the weather, dawn and twilight as well as forest air and bird songs [6].

The forest area of Hani traditional settlement in Yuanyang is less, mainly concentrated in the top of building group. It is the role of water conservation, landslides preventability and biodiversity maintenance.

\subsection{Boundary space}

Generally speaking, if a boundary is properly determined, then its interior can be regarded as its domain, namely, the interior space, the part left, the outer space, and the closed curve on the plane is called the boundary [7].

The woods are usually taken as the boundary in Hani traditional settlement, and the boundary nodes are more obvious. The upper and lower boundary of the village were defined by Mysterious Woods and Swing Square. In addition, the Village Gate is an important boundary node.

\subsubsection{Border Forest}

In Hani traditional settlement, the woods with a certain "thickness" around the buildings are generally regarded as boundary. It separates the settlement of interior space and exterior space. The boundary shape of the forest is guided by the change of the natural environment, so as to form a flexible boundary which is compatible with nature.

\subsubsection{Mysterious Woods and Swing Square}

Mysterious Woods and Swing Square are two important boundary points and are also important elements of the landscape in Hani traditional settlement. There is a special and close relationship between the Mysterious Woods, the Swing Square and the entire settlement. On one hand, on the facade, the Mysterious Woods is located on the top of the building group, and the Swing Square under the building group, both of which control the vertical development of the settlement. On the other hand, from a plane point of view, Mysterious Woods, the center of village and Swing Square constitute the main axis and core elements of the landscape in Hani traditional settlement [8].

Mysterious Woods is the border node above the settlement. Hani people must make sure that there is a large forest on the top of the village to select the site of the village. Then they choose a small piece of forest as Mysterious Woods, and choose a tall, lush and evergreen tree in the Mysterious Woods as the Mysterious Tree. Mysterious Woods is a sacrificial place of the "Angmatu" festival. It is forbidden to enter livestock and prohibit logging at ordinary times. The attention and safeguard for Mysterious Woods and Mysterious Tree of Hani people not only greening the Hani village, but also the function of water conservation is to ensure the drinking for people and livestock and irrigation of paddy field [9].

Swing Square is the border node below the settlement. It is an important sacrificial place and public activity space in Hani traditional settlement. Hani people will choose a relatively flat venue between the village below and terrace as the Swing Square. Surrounded by plants around the Swing Square, a sacrificial room and a swing were set up, and the swing pile was placed in the middle. The Swing Square was not owned by every Hani village, and some villages share a Swing Square.

\subsubsection{Village Gate}

Generally located at the main entrance and exit, the Village Gate is an important landscape node 
in the boundary space. It is an important limiting factor for settlement space. Traditional village gate is comparatively simple, with the construction of trees and branches tied by straw ropes. The Village Gate is the regional boundary between the human and the ghost in the Hani spiritual world, which means that those who live in the village can get shelter and help from God.

\subsection{Interior landscape space of settlement}

\subsubsection{Regional block_biulding group}

The building group is the most important component of the interior space, and is also the central layer of the whole settlement space.

From the overall layout point of view, the building group is distributed along the contour line in accordance with the trend of the mountain, which is showed a large concentration of small decentralized distribution to the group together form. From a local point of view, the building monomer is mainly the mushroom house with its own characteristics in Hani traditional settlement. It constituted the most obvious feature of the interior space. Hani epic "Hani Ape Cong Popo" has this description: "ReLuo mountain is red and green, the mushrooms grow everywhere. Little mushroom is not afraid of wind and rain, beautiful appearance is unforgettable." Mushroom houses interspersed with terraced fields and green forests are closely integrated with the environment., and then a unique scenery of Hani settlement is formed.

The mushroom house belongs to Tuzhangfang type the department of Qionglong, and it's named for its shape like mushrooms. The basic form of Hani mushroom house is characterized by stone foundation, wood structure, mud wall and thatched roof on four slopes. It generally has three floors, including the principal room, side-room, corridor, balcony and the inner courtyard [10]. The mushroom house is warm in winter and cool in summer, ventilated and dry, and local materials are taken, reflecting the living concept and religious beliefs that the Hani in harmony with nature [11].

\subsubsection{Bloodline and skeleton—road system and water system}

\subsubsection{Bloodline——water system}

The importance of water is self-evident. Because there are no obvious rivers and streams in Hani traditional settlement, Hani people have established a set of scientific and reasonable complete water system in long-term practice in order to ensure that limited water resources can meet the needs of life and production. The water system runs through the entire Hani habitat like the capillaries of people.

There is a natural gully around the building group, and ditches are built alongside each building inside the settlement. There are three kinds of ditches: main ditch, branch ditch and field ditch. They are generally located on one side of the road and about 20-50 centimeters in wide, and made of stone or cement, or enclosed with natural soil. These trenches combine to form a free-standing water system that conforms to the terrain and parallels the road. Ditches not only introduce water which from numerous ditches, streams and pools above the village into the village to provide domestic water for Hani people, but also the introduction of domestic sewage into the terraces, and then by the terraced fields down through the field layers of ditch finally into the bottom of the streams and rivers. The water in the rivers and terraces is evaporated and meet with cold air at the mountainside to form clouds and fog, thus forming rainfall in the mountains, buildings, terraces, etc. This cycle is repeated. The water system in series connected the four elements and the whole harmonious ecological system of "mountain and forest — building group-terrace-water system", and it sustains generations of the Hani people live and multiply.

\subsubsection{Skeleton—_road system}

In the long-term development process, the road system of Hani traditional settlement has gradually formed a free-form layout, adapting to the mountain, flexible, smooth and convenient. They are connected in series with each individual building, which is an important landscape element in the interior space of the settlement.

There are three types of roads in Hani traditional settlement. The first is the main road. Hani 
village usually have a main road from the access to important public places, the width of about 2-4 meters, the use of stone pavemen. The second is the home road. These roads irregularly around the building and the main road developed into a free-style layout to connect households, a width of about 1-1.5 meters, the use of stone pavement. The third is the field road, about 0.5 meters wide, bare land is stampede into the road.

\subsubsection{Nodes_—water mill, wells and others}

\subsubsection{Water mills}

Water mills are houses which use water to drive water mill to grind cereal. They are important landscape nodes in settlement. Water mills are generally located in the valley where the greater flow of water place. Their architectural form is the mushroom house, with a waterwheel on one side of the house and a water mill in the house. With the development of society, many water mills in Hani village have long been idle, and no longer in use.

\subsubsection{Wells}

There are usually several wells in Hani traditional settlement. They not only constitute an important symbol of landscape space, but also are an important water source of life. Usually surrounded by stone, the well is composed of a well pool, a shaft wall, a well cover and a water outlet. A complete well system includes the reservoir, well, platform and ditch. Although the entire well system seems simple, it is a manifestation of Hani people's life and ecological wisdom. Next to wells are generally tree-lined. There is an exclusive pond above each well. The water is introduced into the well from the mountain through the pond. The pond mainly plays the role of filtration and purification. At the same time, the water filled in the well flows to the platform below the well through the water outlet for people to wash clothes and vegetables. And then the water flows into the ditch along the water outlet under the well and finally flows down the ditch all the way down into the terraces.

\subsubsection{Others}

In addition to the above-mentioned typical landscape nodes, the interior space of Hani traditional settlement also includes other landscape nodes, such as public activity square, ponds, water tankers and so on. Although they are not in every Hani village, they have distinctive features which further enriches the landscape space composition of Hani Traditional settlement.

\subsubsection{Summary}

The pattern of interior landscape space in Hani traditional settlement can be summarized as: first of all, landscape nodes represented by water mills and water wells provide a venue for public communication while exerting their own functions, which fully played a "point" of the gathering effect. Secondly, the road system and the water system parallel to the road give full play to the "line". They connected the mushroom room-based building monomers in series. At the same time, the water system also linked up the whole village system with the mountain and forest, the building group and the terrace as the core. Thirdly, the mushroom houses in a row are arranged parallel to the contour line, forming a "block surface" of the building group due to the consistency of their shapes and materials. Finally, the combination of these landscape elements constitutes a distinctive feature of the interior landscape in Hani traditional settlement.

\section{Conclusion}

To sum up, the hierarchical pattern language of the landscape space on Hani traditional settlement is summarized as follows:

At the macro level, pattern language I: The buildings of Hani traditional settlement built in accordance with the trend of the mountain, and the mountains are covered by terraced fields. Pattern language II: The group of mushroom house is located in the mountainous area of $800-2000$ meters above sea level. Pattern language III: Buildings are generally located in the "concave pond" of wind 
and air reservoir, and surrounded by mountains.

At the meso level, pattern language I: Hani settlement formed a "mountain and forest - building group - terrace - water system" top-to-bottom vertical circulation of living environment ecosystem. Pattern language II: Hani settlement formed a "building group - forest ring - terrace " circle space structure from inside to outside.

At the micro level, the first is the exterior landscape space of settlement. Pattern language I: Ladder-like terraced layers are beautiful and changeable. Pattern language II: A small forest above the building group are eco-friendly. The second is the boundary space. Pattern language I: Mysterious Woods, the village center and Swing Square formed a landscape spindle. Pattern language II: As the upper boundary, the Mysterious Woods played the role of virescence and water-conservation. Pattern language III: As the lower boundary, the Swing Square is a sacrificial place, and there is a swing and a pile. Pattern language IV: The Village Gate is the regional boundary between man and ghost. Pattern language V: The "Border Forest" around the building group is in harmony with nature. The third is the interior landscape space of settlement. The pattern language of architecture I: Mushroom house is a symbol of village, which is distributed in large concentration and small dispersed group. The pattern language of architecture II: The mushroom house shaped like a mushroom is stone foundation, wood structure, mud wall and thatched roof on four slopes. The pattern language of architecture III: The building materials of the mushroom house are locally sourced, and it is warm in winter and cool in summer, ventilated and dry. The pattern language of water system I: The water system paralleled with the road and conform to the topography, free-style cycle. The pattern language of water system II: The water system runs through the settlement and connects the various elements of the landscape ecosystem in series. The pattern language of water system III: The water system includes natural ditch and artificial ditch in two forms. The pattern language of road system I: The road system is a free-form layout that adapts to the mountain, is flexible and patented. The pattern language of road system II: The road system is generally paved with stone. The pattern language of landscape nodes I: Water mills in the form of mushroom house are important landscape nodes. The pattern language of landscape nodes II: The pond, well, platform and ditches form a well-integrated scientific well system.

In a word, the pattern language of different levels on the landscape space of Hani traditional settlement has different functions and plays different roles. They restrict and interact with each other, and form the distinctive landscape of Hani traditional settlement. At the same time, it also constitutes a complete pattern language system of Hani traditional settlement (Table 1).

Table 1 The pattern language system of the landscape space on Hani traditional settlement in Yuanyang.

\begin{tabular}{|c|c|c|c|c|}
\hline Study on level & \multicolumn{3}{|c|}{ Research object } & The pattern language of the landscape space \\
\hline Macro level & \multicolumn{3}{|c|}{ The whole landscape space of settlement } & $\begin{array}{l}\text { Located in the hillside of the "concave pool"+ } \\
\text { Surrounded by "mountains package" }\end{array}$ \\
\hline \multirow{2}{*}{ Meso level } & \multicolumn{3}{|c|}{$\begin{array}{c}\text { The landscape space of settlement from plane } \\
\text { angle }\end{array}$} & $\begin{array}{l}\text { A "building group - forest ring - terrace " circle space } \\
\text { structure from the inside to outside }\end{array}$ \\
\hline & \multicolumn{3}{|c|}{$\begin{array}{c}\text { The landscape space of settlement from facade } \\
\text { angle }\end{array}$} & $\begin{array}{l}\text { A "mountain and forest - building group - terrace-- } \\
\text { water system" vertical structure from top to bottom }\end{array}$ \\
\hline \multirow{6}{*}{ Micro level } & \multicolumn{3}{|c|}{ Exterior landscape space of settlement } & Large area terrace + Small area forest \\
\hline & \multicolumn{3}{|c|}{ Boundary space } & $\begin{array}{c}\text { Border Forest + Mysterious Woods + Swing Square+ } \\
\text { Village Gate }\end{array}$ \\
\hline & \multirow{4}{*}{$\begin{array}{c}\text { Interior } \\
\text { landscape } \\
\text { space of } \\
\text { settlement }\end{array}$} & & $\begin{array}{l}\text { Surface-Regional } \\
\text { lock-Biulding group }\end{array}$ & $\begin{array}{l}\text { The combination of mushroom house as building } \\
\text { monomer = Group-style buildings }\end{array}$ \\
\hline & & \multirow{2}{*}{ line } & Bloodline-Water system & $\begin{array}{c}\text { A "natural ditch + artificial ditch" free-circulating water } \\
\text { system }\end{array}$ \\
\hline & & & Skeleton—Road system & $\begin{array}{l}\text { A "main road + home road + field road" free-style road } \\
\text { system }\end{array}$ \\
\hline & & \multicolumn{2}{|c|}{ Point-Node-Landscape node } & water mill + well + others \\
\hline
\end{tabular}

It is a long-term and systematic work to protect and develop the landscape of ethnic traditional settlement. It is necessary to summarize a set of operational method and development model 
suitable for the ecological landscape construction of each ethnic settlement. It is hoped that the pattern language of landscape space on Hani traditional settlement constructed in this paper can provide reference for the protection, inheritance and development of Hani traditional settlement and other traditional settlements. It will be taken as the initial stage of research, be gradually promoted, improved and perfected gradually. In the end, we will step out of a sustainable development path suited to the ecological environment and unique landscape of minority settlements.

\section{Acknowledgement}

This work was funded by National Social Science Fund Project "Study on the Ecological Protection and Sustainable Development of the Ethnic Villages in the Southwest China in the Context of Urbanization" (15XMZ089) and by Yunnan Province Philosophy and Social Science Planning Fund Project in Art Discipline "Study on Landscape Design and Regional Cultural Characteristics in Yunnan Province” (A2015YBS005).

\section{References}

[1] Liu Peilin. Landscape and Dene of Homeland[M]. Beijing: The Commercial Press, 2014: 3.

[2] Hu Haisheng, Tang Daijian. Review and prospect of cultural landscape research[J]. Geography and Geo-Information Science, 2006, 22(5): 95-100.

[3] Luo Deyin. The ultimate use of Hani terraces as the ultimate landscape[J]. World Heritage, 2014, (9): 42-47.

[4] Jiang Xiaochen. The model language analysis of architectural design of Huizhou culture park based on concept of health preserving [D]. Hefei: Hefei University of Technology, 2013: 10-12.

[5] Chen Fuqun. Study on the pattern language of landscape in traditional settlement in the southern part of Hunan [D]. Changsha: Hunan Normal University, 2015: 11-14.

[6] Jiang Qi. Study on the landscape imagery of Zhangguying Village[D]. Changsha: Central South University of Forestry and Technology, 2014: 39.

[7] Guo Nan. Study on the inheritance and development of space form on traditional settlements under the background of urbanization_ A case study of Yunnan Province[D]. Kunming: Kunming University of Science and Technology, 2010: 33.

[8] Zong Luping, Jiao Yuanmei. Rural settlement landscape and evolution in heritage area of Hani terraced_-A case study of Quanfuzhuang Village in Yuanyang, Yunnan Province[J]. Tropical Geography, 2014, 34(6): 66-75.

[9] Cao Guixiong. Construction of ecological civilization and ethnic characteristic villages_-Take Hani traditional villages as an example[J]. Journal of Honghe University, 2014, 12(1): 13-15.

[10] Yang Dayu, Zhu Liangwen. Yunnan Dwellings[M]. Beijing: China Architecture \& Building Press, 2009: 100-104.

[11] Gao Kai. Form and god of the cultural landscape on Hani terrace in Honghe[J]. Journal of Kunming University of Science and Technology (Social Science Edition), 2013, 13(6): 91-97. 